\title{
POST-TRAUMATIC STRESS AMONG ORTHOPAEDIC TRAUMA PATIENTS
}

\author{
*Mrs. K. Sathiya, **Dr. Prasanna Baby \& ***Mr. R. Vijayaraj
}

\section{Introduction}

Post-traumatic stress disorder (PTSD) is a mental illness that can occur after injury. It was first described among soldiers who had been in combat and experienced severe emotional or physical trauma. It is part of the body's response to a horrible situation. Orthopaedic nurses should thoroughly evaluate all patients for PTSD by looking for changes in patient's normal behavior including anger, agitation, feeling numb or detached from the accident, flashbacks, headache, insomnia, irritability, lack of interest in daily activities and nightmares. A serious PTSD can have a negative impact on their quality of life ${ }^{.1}$

\section{Statement of the problem}

A study to assess the stress among orthopedic trauma patients in a selected hospital in Chennai.

\section{Objectives}

- Assess the level of stress among patients subjected to major orthopaedic trauma

- Associate the level of stress with selected background variables among patients subjected to major orthopaedic trauma

\section{Methodology}

Research design - Descriptive non experimental design

Setting - Selected hospital at Chennai

Population - Major orthopaedic trauma patients

Sample size - 30
Sampling technique - Non- probability convenient sampling technique

\section{Criteria for sample selection}

Inclusion criteria

- Patients who were in the age group between 18- 57 years

- Both male and female patients who had major orthopaedic trauma in upper and lower limbs.

- Patients who understood and spoke Tamil or English

Exclusion criteria

- Seriously ill patients

- Patients who were not willing to participate in the study. ${ }^{2}$

\section{Description of the tool}

The tool of this study had two sections

\section{SECTION A}

Consisted of back ground variables such as age, sex, type of family, occupation, socioeconomic status, frequency of trauma and duration of hospital stay. ${ }^{3}$

SECTION B

Perceived stress scale with 10 items and each item carries maximum 4 , minimum 0 . It is like 4 points Likert's scale

\section{Score interpretation}

\begin{tabular}{|l|l|l|}
\hline S.No & \multicolumn{1}{|c|}{ Level of stress } & Score \\
\hline 1. & Mild & $1-13$ \\
\hline 2. & Moderate & $14-26$ \\
\hline 3. & Severe & $27-40$ \\
\hline
\end{tabular}

*Lecturer, **Principal, Faculty of Nursing, SRU \& *** Asst. Prof, KGNC, SBV. 


\section{Findings}

1. Frequency and percentage distribution of background variable among patient subjected to major orthopaedic trauma

Regarding the age 15(50\%) patients belonged to 21-30 years of age group, $7(23 \%)$ $31-40$ years and $8(27 \%)$ patients were $41-50$ years of age.

With regard to gender, 25(83\%) patients were male and 5(17\%) patients were female

With respect to occupation, $7(23 \%)$ patients were doing daily wage work, $15(50 \%)$ patients were doing private jobs, $3(10 \%)$ were doing government jobs and 5(175) patients were self employed.

With regard to duration of hospitalization, 9(30\%) patients were hospitalized for less than 2 weeks, 20(67\%) patients were hospitalized for 2-4 weeks and $1(30 \%)$ patient was hospitalized for $>4$ weeks.

Regarding type of family 18(60\%) patients were belongs to nuclear family and $12(40 \%)$ patients from joint family.

With respect to frequency of trauma, $13(43 \%)$ patients experienced trauma $<2$ times, $15(50 \%)$ patients $2-4$ times and $2(7 \%)$ of them $>4$ times experienced trauma.

2.Percentage distribution of stress among patients subjected to major orthopedic trauma $\mathrm{N}=30$.

\begin{tabular}{|l|l|l|l|l|l|l|}
\hline \multirow{2}{*}{$\begin{array}{l}\text { S. } \\
\text { No }\end{array}$} & \multicolumn{2}{|c|}{$\begin{array}{c}\text { Mild } \\
\text { stress }\end{array}$} & \multicolumn{2}{c|}{$\begin{array}{c}\text { Moderate } \\
\text { stress }\end{array}$} & \multicolumn{2}{c|}{$\begin{array}{c}\text { Severe } \\
\text { stress }\end{array}$} \\
\cline { 2 - 7 } & NO & $\%$ & NO & $\%$ & NO & $\%$ \\
\hline & 3 & 10 & 24 & 80 & 3 & 10 \\
\hline
\end{tabular}

This table depicts that $3(10 \%)$ of them had mild stress, 24(80\%) had moderate stress and $3(20 \%)$ had severe stress.
There was a significant association between age, sex, marital status and duration of hospital stay with the level of stress $p<0.001{ }^{4}$

\section{Implications}

\section{Nursing Practice}

Nurses are playing vital role in health care system and she act as a liaison officers among patient, family members and health care team members. She should inform then and there about patient prognosis to the patient and family members. Nurses should update their knowledge by participating in in service education and workshop regarding stress management technique.

\section{Nursing Education}

The Nurse educator is responsible to educate nursing students how to manage the stress among orthopaedic patients through evidence based practice in different methods of teaching.

\section{Nursing Administration}

The Nursing Administrator can organize inservice education to facilitate Nurses in understanding the stress and the inservice education should be conducted separately for orthopaedic staff based on the needs of the patients.

\section{Nursing Research}

Nursing research is an important measure for Nursing to become a profession. The practicing Nurses need to be encouraged to conduct research based on the issues faced while rendering care to the patients. The Nursing experts and mentors must motivate and support the Nurses to conduct the research and utilize the research findings into practice. ${ }^{5}$

\section{Conclusion}

Perceived stress scores were remarkably high among orthopaedic patients. This may be 
due to lack of information to patients and family members about prognosis. Evidence based nursing practice must take a higher profile in order to increase awareness of various stress management techniques to the patients. Nurses have a vital role in teaching the patients the coping strategies both in the hospital and in the community.

\section{Reference}

1. Lewis.et.al. Medical Surgical Nursing. Philidelphia. Mosby publishers; 2004.

2. Brewin CR, Andrews B, Valentine JD. Metaanalysis of risk factors for posttraumatic stress disorder in trauma-exposed adults. Journal of
Consult Clinical Psychology. 2013 vol-68, No-5 page No-748-766.

3. Charney D, Psychobiological mechanisms of resilience and vulnerability: implications for successful adaptation to extreme stress. American Journal orthopaedics, 2013 vol-161, No-2 page No-195-216.

4. Sundar Rao P.S. Introduction to Biostatistics and Research Methods. New Delhi. Prentice Hall of India private Limited;2006.

5. Wood. G. Haber. Nursing Research methods Critical apprasial and utilization. London. Mosby publication; 1994. 